総 説

\title{
食嗜好評価に基づく冷凍米飯の最適保蔵温度条件 一高齢者の食嗜好と粘弾性特性の相関関係分析法一
}

\author{
相 良 泰 行 ${ }^{\S}$ \\ (社)食感性コミュニケーションズ (FKC)
Optimum Condition of Preservation Temperature for Frozen Cooked Rice Based on Sensory Evaluation of Food Preference
-Correlation Analysis Method Between Food Preference of the Aged and Viscoelastic properties-

Yasuyuki Sagara ${ }^{\S}$

Food Kansei Communications, Corp. (FKC)

\section{1. はじめに}

食感性工学のパラダイム ${ }^{1)}$ を実現する基盤モデルとして, ヒトが感じる「おいしさ」を定量的に評価する機能を有す る「食感性モデル」を提唱し ${ }^{2}$, このモデルの有用性を実証 するために, 消費者の感性を考慮した緑茶飲料の香味設計 法およびペットボトルの視覚情報が香味評価に及ぼす影響 などについて紹介した。 また，味と香りの感性計測システ ム ${ }^{3)}$ では，味覚・嗅覚センサーや $\mathrm{GC} / \mathrm{O}$ によるコーヒーア ロマを保持するための最適凍結乾燥温度条件の探索法を紹 介し，食感性モデルは食品製造プロセスのコントロールに あ利用可能でありことを示した。しかし，テクスチャーの 感性計測法 ${ }^{4)}$ については既存の機器計測法により得られる 測定結果と官能評価による官能值とが必ずしも一致しない 現状にあることを述べた。

本稿では食感性工学の理念を念頭におきながら, 研究開 発の計画や到達目標を設定するグランドデザインの考え方 と, 凍結保存した米飯の解凍後における粘弾性特性と官能 評価スコアに関するデータセットから, 最適な冷凍保存温 度条件を探索した研究事例について紹介する。ここに紹介 する方法は消費者の嗜好特性を考慮した，すなわち消費者 を起点とした新食品の開発や加工条件の最適化に有用であ ると考えられる.

具体的には,「食感性モデル」の食品属性として定義した 「物理化学的特性」として, 冷凍米飯の粘弾性特性などを計

テ101-0061 東京都千代田区三崎町 2-8-7 大庄ビル 3 階

$\S$ 連絡先 (Corresponding author), sagara@foodkansei.or.jp
測し，また，ヒトの「感情（おいしさ）」を評価する方法と して，一般成人および高齢者を対象とした官能評価を実施 した.これらの計測・評価結果に, 機器計測值と官能值と の相互関係を探索する典型的解析手法として, ニューラル ネットワーク (Artificial Neural Network: ANN) モデ ル (5) 7) を採用することとし，以下に示すような研究目的を 設定した.

1）凍結・保存温度条件の異なる米飯を対象とする官能 評価スコアより一般成人および高齢者の米飯に対す る食嗜好特性の相違を明らかにする.

2）米飯の保存温度・時間，粘弾性特性計測デー夕およ び官能評価により得られた評価スコアから最適な保 存温度条件を探索する方法を開発する.

3）前項と同様なデー夕および探索法から得られる最適保 存温度条件の汎用性, 例えば品種依存性を検討する。

4）粘弾性パラメータから一般成人および高齢者が感じ る「おいしさ」をそれぞれ予測し, ANN 分析法が米 飯の機器測定データから両者が感じる「おいしさ」 を予測するのに有用であることを示す.

5）凍結保存による品質劣化の要因を探るための基礎資 料を得るために，異なる温度で涷結保存した米飯の 1 粒子内に形成される水結晶の性状を 3 次元的に可 視化する方法の開発を試みる.

これらの多様な目的を達成するためには, 研究の意義と 重要性, ニーズと社会貢献，技術レベルの現状などの検討 結果に基づく総合的研究計画，すなわち「グランドデザイ ン」の策定が重要である. 次節以降には, 研究の初期段階 
で実施した情報探索結果について要約し, 研究従事者がこ れらの情報を共有して全体計画の中の自分の役割を認識し ながら研究意欲を高めるのに役立てた事例を紹介する。

\section{2. 冷凍米飯の生産・消費・研究の現状}

日本統計協会によると，総人口に占める高齢者人口の割 合は約 $18 \%$ となっている（表 1) ${ }^{8}$. このような高齢化に加 え, 食の安全性への消費者意識の高まりに伴って,「おいし く簡単に食べられる健康で安全な食」の提供が急務となっ ている，とりわけ我々の主食である米飯に関しては，その 簡便さと安全性確保から冷凍米飯が広く利用されており（表 2), 平成 14 年には全加工米飯生産量の $59 \%$ を占めるまで に至っている（図 1).

表 1 総人口に占める高齢者（65 歳以上）の割合

\begin{tabular}{cccc}
\hline \hline & $\begin{array}{c}\text { 総人口 } \\
\text { [万人 }\end{array}$ & $\begin{array}{c}\text { 65 歳以上人口 } \\
\text { [万人 }]\end{array}$ & $\begin{array}{c}\text { 総人口に占める割合 } \\
{[\%]}\end{array}$ \\
\hline 昭和 45 年 & 10467 & 739 & 7.1 \\
昭和 50 年 & 11194 & 887 & 7.9 \\
昭和 55 年 & 11706 & 1065 & 9.1 \\
昭和 60 年 & 12105 & 1247 & 10.3 \\
平成 2 年 & 12361 & 1489 & 12.0 \\
平成 7 年 & 12557 & 1826 & 14.5
\end{tabular}

しかし，冷凍米飯の品質や食味に関する研究は，精白米 に関する研究と比較して数少なく，例えば米の品種・炊飯 法・凍結法・貯蔵温度・解凍法などが米飯の物理的特性に 及ぼす影響に関する報告9) 15) がなされているが，冷凍米飯 の加工・保存条件が物理化学的特性や「おいしさ」に与え る影響については系統的に解明されていない現状にある. このために，例えば高齢者を対象にした介護食弁当の主食 として, 健康・生活習慣病予防機能を有する冷凍米飯を開 発しても，その食味がまずければ継続摂食を拒否され，さ らには消費が伸び悩む事態を招くことになりかねない。こ のように，冷凍米飯の「おいしさ」を定量的に把握して消 費者の嗜好に合致した製品を設計・製造することや，食味 を保持するための最適な冷凍・保存温度条件を明らかにす ることは重要な研究課題であることが分かった。

\section{3. 米飯の食味評価法 ${ }^{16) ~ 18) ~}$}

米飯の食味評価には，炊飯米をサンプルとした官能評価 および食味に関連の深い物理化学的特性を機器計測・分析 により評価する方法が行われている．物理化学的特性に基 づく評価法の例としては，アミロースやタンパク質の測定， 炊飯特性試験, 糊化特性試験, 米飯物性測定などが挙げら れる。これらの特性の中であ，米飯の食味には，その「硬 さ」や「粘り」のような粘弾性特性が強く影響することが

表 2 加工米飯の種類別生産量

（単位 $\mathrm{t）}$

\begin{tabular}{|c|c|c|c|c|c|c|c|c|c|}
\hline & 平成 6 年 & 平成 7 年 & 平成 8 年 & 平成 9 年 & 平成 10 年 & 平成 11 年 & 平成 12 年 & 平成 13 年 & 平成 14 年 \\
\hline 冷凍米飯 & 109594 & 128753 & 137809 & 141520 & 146155 & 177813 & 153240 & 161288 & 146075 \\
\hline 無菌包装米飯 & 11035 & 17945 & 18781 & 27214 & 34787 & 53259 & 55615 & 58246 & 66316 \\
\hline レトルト米飯 & 21507 & 25341 & 21976 & 21190 & 21783 & 23795 & 22892 & 22834 & 21840 \\
\hline チルド米飯 & 3177 & 3591 & 5827 & 5217 & 5486 & 5573 & 7046 & 9794 & 6686 \\
\hline 乾燥米飯 & 3444 & 4232 & 4326 & 4554 & 3743 & 4073 & 3512 & 4587 & 4907 \\
\hline 缶詰米飯 & 1874 & 2907 & 1752 & 1586 & 1926 & 2099 & 1906 & 1973 & 1923 \\
\hline 合計 & 150631 & 182769 & 190471 & 201281 & 213880 & 266612 & 244211 & 258723 & 247747 \\
\hline
\end{tabular}

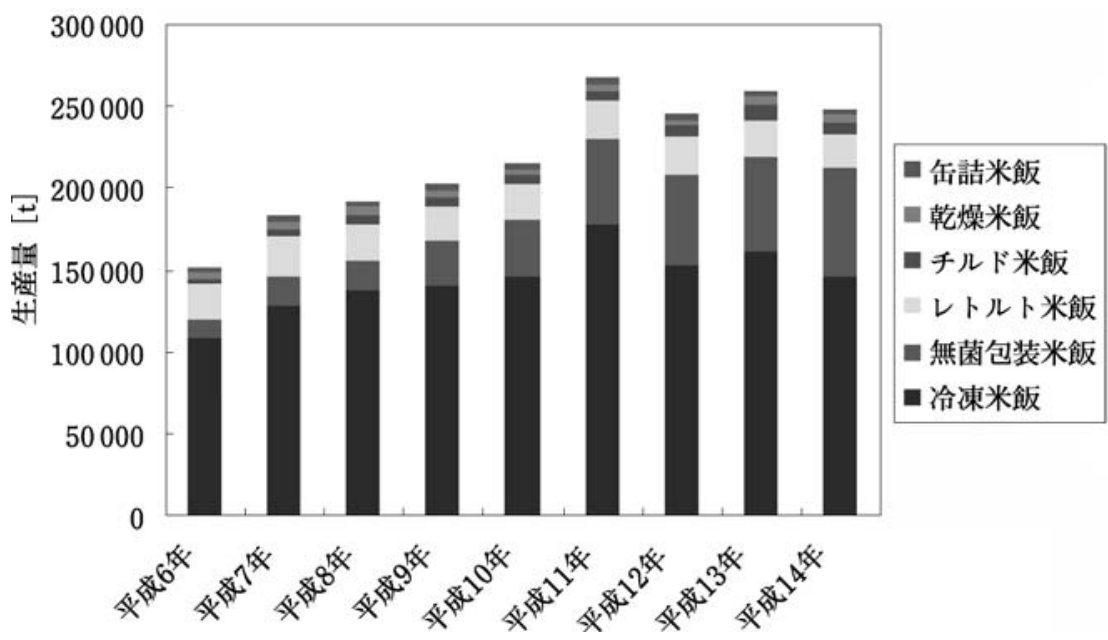

図 1 加工米飯生産量に占める冷凍米飯の割合 
指摘されており，その測定機器として，テクスチュロメー 夕, レオメータ, 万能圧縮引張試験機およびテンシプレッ サなどが広く使われている19) 24). しかし，これらの測定結 果と官能值, 特に米飯の総合的な「おいしさ」との関係は 不明である。例えばテクスチュロメータ ${ }^{24)}$ はその測定結果 の波形からヒトが感じる「かたさ」「粘り」「割れやすさ」な どを表示する機能を有しているが，これらのテクスチャー に関するパラメータの計測結果と官能值とは必ずしも一致 しないことが知られている。すなわち機器計測の結果から 官能值を正確に予測することは不可能な現状にある.

他方, 米飯の成分および水分分布に関する研究例 ${ }^{25)}$ とし て，米粒子内におけるデンプン，タンパク質および脂質な どの分布を計測した結果や, 米飯粒子内の水分分布を NMR ミクロイメージング26 29) を用いて 3 次元的に可視化した 研究が報告されている。 NMR は液体または溶液状態で存 在する化合物に含まれるプロトンを検出し, 水, 油, 糖, アミノ酸, 芳香族化合物の分布と性質をマッピングする機 能を有しており．特に水をマッピングすることによって， 試料の組織の内部構造を非破壊的に計測できる特徵を有し ている.しかし, 米飯の食味に関する研究報告は, 精白米 を対象とした膨大な研究例と比較して数少なく, 口腔内で 知覚されるテクスチャーについても, その定量的知見は得 られていない現状にある。 また成分, デンプンの糊化度お よび水分分布など, 米飯の物理化学的な定量的デー夕を測 定・報告した研究例む数少ない現状にある。

\section{4. 研究の達成目標}

本総説シリーズでは，上述したような研究の現状にブ レークスルーをむたらす方法として，「食感性モデリング」2) を提唱した. 本研究例む「食感性モデリング」のアイデア を具体的に展開し，その有用性を実証した事例に相当す る. その達成目標は, 米飯の粘弾性測定および官能評価に 基づき, 冷凍米飯の品質保持に最適な冷凍・保存温度条件 を明らかにすること，さらには一般成人および高齢者の啫 好特性の相違を把握し, 解凍後における米飯の物性值から 一般成人および高齢者が感じる「おいしさ」をそれぞれ予 測することにより，これら社会属性の異なる消費者の嗜好 を満足させる米飯を提供するための最適冷凍・保存温度条 件を明らかにすることにある。これらの条件は米飯製造工 程の設備機器の制御やプロダクトマネージメントに有用な 情報を提供するあのと考えられる.さらにこれらの個別技 術を総合化して，例えば「少子高齢化社会に対応した冷凍 宅配弁当フォードシステム」30) 構築し, 地域社会システム のモデルとして提案することも可能になると考えられた。

\section{5. 研究のグランドデザイン}

\section{1 デザインの留意点}

食感性モデルを有効に活用するためには, 総合的な研究
計画，すなわち「グランドデザイン」が必要である。さら に，立案されたグランドデザインに従って，あらかじめ測 定項目と採用すべき計測機器類および計測・評価のための 手法を検討しておく必要がある. 本研究の目標を達成する ためには, 食感性モデルの構成要素である食品属性の中の 「物理化学的特性」からヒトの「おいしさ」に至る知覚の経 路 ${ }^{2)}$ に着目し, 少なくとも前者に関する機器計測デー夕と 後者に関する評価スコアの取得法をそれぞれ確定しなけれ ばならない.しかし，この段階では官能評価により得られ る「知覚強度」および「おいしさ」に関するスコアと関連 を有する米飯の「物理化学的特性」の測定項目は明らかで ない，そのために，理想的には食品の物理化学的特性の計 測には現存する全ての計測法を採用すべきである.

ヒトが感じる「かたさ」に寄与する要因は単に粘弾性パ ラメータのみでなく糖度・酸度, 含水率などの含有化学成 分量に影響される ${ }^{4)}$. すなわち, 従来の研究で行われてき たように，テクスチャーを計測するために開発された工学 的計測機器を用いて, 力学的パレメータのみを計測しても, 得られたデータからヒトが感じる「かたさ」を正確に予測 することは不可能であることに留意すべきである．「食感 性モデル」の利点の一つはモデルに含まれる要因間の関連 性の強さを定量的に判定できる点にある。例えば食品の香 りを抽出またはサンプリングする多様な方法の中から, 官 能評価スコアとの関連性が高い抽出法を選択する事が可能 となる点である。このように，食感性モデルは物理化学的 特性の計測法の中から，ヒトが知覚している食品の成分や 理工学的特性を計測する方法を探索するッールとして利用 することも可能であるといえる.

\section{2 研究手法のデザイン}

グランドデザインの第 1 ステップとして, 本研究の目的 を達成するための全体的なスキームを図 2 に示した。四中 には計測項目を最下段に, 計測により得られたデータ群に ANN を適用して明らかにする課題を中段に示し，最上段 には計画した研究の最終目的を示している. 最下段に示し た計測項目の中で,「水結晶計測」は, 研究を開始する時点

\section{社会属性の異なる消費者の喍好を満足 させる米飯を提供するための最適冷凍・ 保存温度条件を明らかにすること}

\begin{tabular}{c|c} 
冷凍米飯の品質保持 \\
に最適な冷凍・保存条 \\
件を明らかにする物㥀から一般成人 \\
および高榆者の「おい \\
しさ」を予測すること
\end{tabular}

図 2 研究のスキーム 
で，その計測手法が確立されておらず，本研究を遂行する 過程で，新規に開発することを計画した計測項目である. 具体的には筆者らが開発した「マイクロスライサ画像処理 システム」を利用して，米飯 1 粒子内に形成される 3 次元 水結晶構造を計測する新たな手法を開発することとした。 この開発が達成されると, 冷凍米飯の凍結速度-水結晶構 造一解凍後の品質の関連性を定量的に評価することが可能 となる事が予測されるが, 本研究のスキームの中での達成 レベルとして，少なくとも凍結温度と保存期間により変化 すると予測されている水結晶構造の 3 次元可視化画像を計 測可能とするレベルを目標とした.

\section{3 測定項目・設定条件と手順}

前項のグランドデザインに引き続き, 第 2 ステップとし て策定した，より詳細な研究手順を図 3 に示す。この手順 に従って検討した実験条件や方法の検討結果を次項以降に 述べる。

\section{1）供試材料}

おいしさの程度が異なる 2 つ品種の冷凍米飯製造に対 する適性を判定することを目的とし, 米の食味計 ${ }^{3)}$ で 90 点 以上の最高評価点と約 75 点を示すことが知られている 2 つの品種, すなわち新潟県魚沼産の「コシヒカリ」と滋賀 県産「日本晴」のいずれも新米を供試材料として選択した。

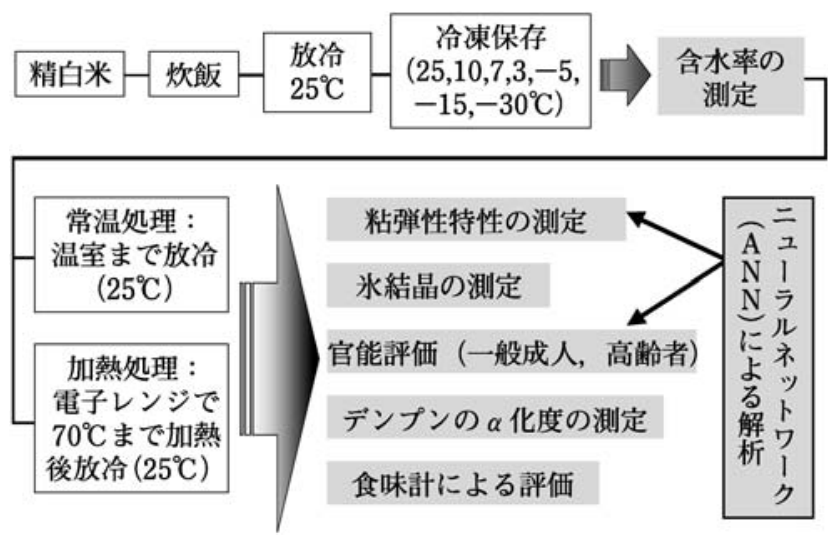

図 3 測定項目・設定条件と研究の手順
2）炊飯・放冷法

これらの方法については, 現在, 健康・介護食を生産し ている民間企業の品質管理手法を参考にして決定した. 具 体的には，精白米 $500 \mathrm{~g}$ をアルミニウム製ボウルに入れ， 水道水 $800 \mathrm{ml}$ を加えて直ちに水を切り, 10 回研いだ後, 水道水 $800 \mathrm{ml}$ を加えて水を切る操作を 2 回, 水道水 1200 $\mathrm{ml}$ を用いて約 10 秒間攪拌しながらすすぐ操作を 4 回繰り 返した。続いて米重量の 1.36 倍の水道水を加え, 家庭用炊 飯器を用いて普通炊きのコースで炊飯した。

炊飯終了直後に蓋を開け, 工業用吸水シートの表面に炊 飯器内の釜を転倒し，ライスケーキ状試料を取り出した. 次に, 炊飯器付属のしゃもじを用いて釜面に接していた部 分の米飯を $300 \mathrm{~g}$ 削り取り，軽く攪拌した後，厚さ $20 \mathrm{~mm}$ に広げて室温 $25^{\circ} \mathrm{C}$ まで放冷後, シートに包んで 15 分間な じませた。なお，試料の炊飯および放冷時における試料中 心温度の径時変化を熱電対によりモニターした。

3）保存温度と保存期間

前項で述べた方法により室温まで放冷した後の試料 200 $\mathrm{g}$ をポリエチレン製容器に入れ，塩化ビニル樹脂製食品包 装用ラップフィルムで二重に包装した後, 設定温度に対し て $0.2^{\circ} \mathrm{C}$ の精度で制御が可能な小型低温恒温器内に冷蔵

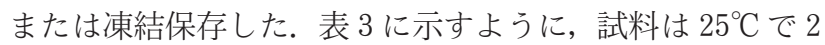
日間, $10^{\circ} \mathrm{C} \cdot 7^{\circ} \mathrm{C} \cdot 3{ }^{\circ} \mathrm{C}$ で 3 日間, $-5^{\circ} \mathrm{C} \cdot-15^{\circ} \mathrm{C} \cdot-30^{\circ} \mathrm{C}$ で 10 日間保存して, その後の計測および官能評価に供し た。また，保存期間中の試料について一定時間ごとに含水 率を $105^{\circ} \mathrm{C}-24 \mathrm{~h}$ 炉間法により測定した。保存後の試料は 含水率測定後に 2 分し, 一方は自然放置して試料温度を室 温まで上昇させて「常温処理試料」, 他方は家庭用電子レン

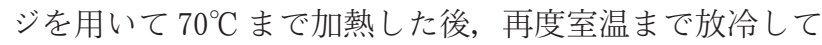
「加熱処理試料」とした.

4）計測・評価・ANN 分析の手順

これらの試料について，レオメータを用いたクリープ試 験およびテンシプレッサを用いた低・中・高圧縮 6 バイト 試験による粘弾性特性, デンプンの糊化度をそれぞれ測定 し，さらに炊飯米用食味計を用いた食味評価および官能評

表 3 試料の保存温度条件および物性測定・官能評価時間の設定

\begin{tabular}{c|ccccccccc}
\hline \hline 温度 $\left({ }^{\circ} \mathrm{C}\right)$ & \multicolumn{7}{|c|}{ 時間 $(\mathrm{hr})$} & \multicolumn{1}{c}{ 時間 (day) } \\
\hline 25 & $0 *$ & - & 2 & 5 & 24 & 48 & - & - & - \\
\hline 10 & 0 & 1 & 2 & 5 & 24 & 48 & 72 & \\
\hline 7 & 0 & 1 & 2 & 5 & $24 *$ & 48 & 72 & - & - \\
\hline 3 & 0 & 1 & 2 & 5 & 24 & 48 & 72 & - & - \\
\hline-5 & 0 & - & - & - & 1 & - & 3 & 5 & 10 \\
\hline-15 & 0 & - & - & - & $1 *$ & - & 3 & 5 & 10 \\
\hline-30 & 0 & - & - & - & 1 & - & 3 & 5 & 10 \\
\hline 備考 : & は一般成人を, * は一般成人と高齢者を対象とした官能評価実施筒所を示す.
\end{tabular}




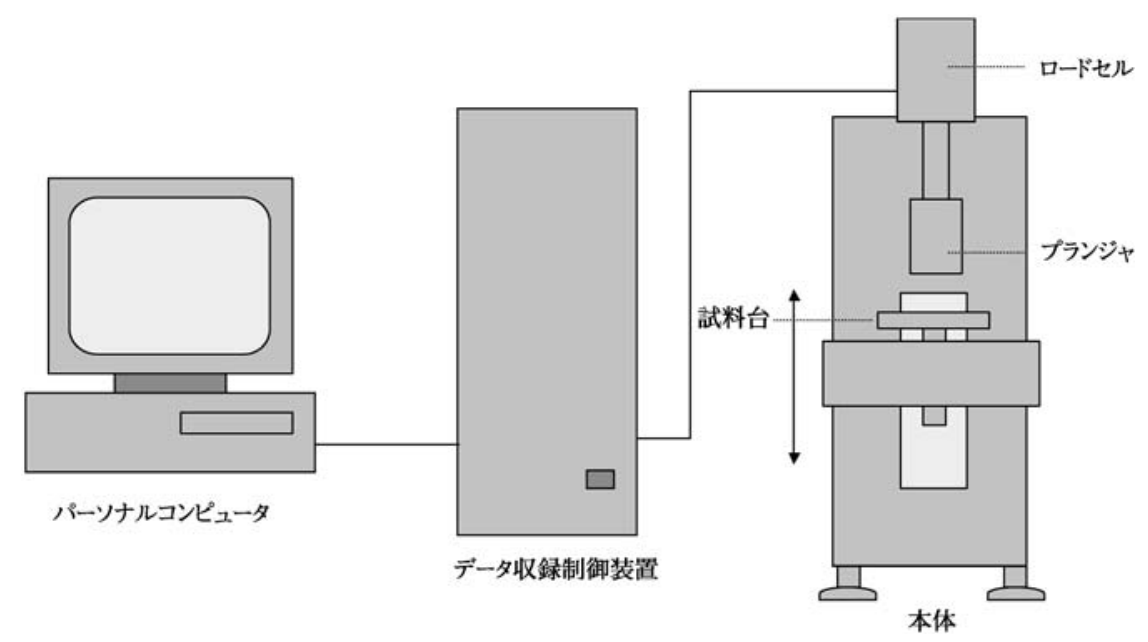

図 4 テンシプレッサの概略図

価を実施した。このようにして得られた計測・評価結果 データに ANN モデルを適用して解析し, 保存温度・期 間・粘弾性パラメータおよび官能評価により得られる「項 目得点」と「おいしさ」の関係をそれぞれ明らかにした.

\section{6. 粘弾性計測装置と方法}

\section{1 テンシプッレッサ}

前節で述べたように, 米飯の保存後における粘弾性特性 デー夕を取得するために，レオメー夕による炊飯米 1 粒子 の破断およびクリープ試験と, テンシプレッサによるバル ク状試料の粘弾性特性計測を実施した。しかしながらレオ メータによる計測データから判別可能な傾向を把握するこ とは困難であった。これの原因は装置の試料台に供試した 米飯 1 粒子の姿勢を常時一定に保つ事が困難であったため であり，これに起因して取得データの測定誤差が増大した あのと考えられた。したがってその後の ANN 解析にはテ ンシプレッサにより得られたデータを採用した。

図 4 に米飯の粘弾性計測に用いたテンシプレッサの概略 図を示した。この図に示すように，テンシプレッサは本体， デー夕収録制御装置および解析用パーソナルコンピュータ から構成されており, 本体はパーソナルコンピュータから 操作することが可能である. 本体の試料台は一定速度で垂 直方向に昇降して試料を連続的に圧縮すると同時に, ロー ドセルにより圧縮・引張りに要する力・仕事量と変形距離 を検出する機能を有している。 この装置の特徵は, 試料を 23〜 92\%の範囲で設定した 3 段階の低・中・高圧縮を各 段階について連続的に 2 回繰り返す方法, すなわち 6 バイ 卜試験における力-時間曲線を測定し, 得られた曲線の波形 （図 5）から「硬さ」，「こし」，「付着性」および「粘り」な どのパラメータ值を表示する機能を有している点にある.

\section{2 計測方法}

表 3 に示した温度・時間条件下で保存した常温処理試料

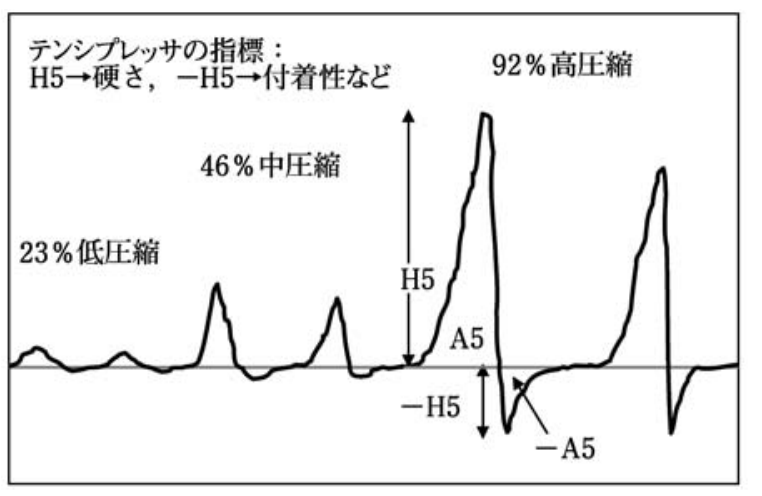

(1) (2) (3) (4) (5) (6)バイト数

図 56 バイト試験計測曲線

および加熱処理試料それぞれについて，6 バイト試験によ る粘弾性特性を測定した。試料 $10.0 \mathrm{~g}$ を内径 $40 \mathrm{~mm}$ 高さ $16 \mathrm{~mm}$ の円筒状試料容器入れ, 専用プランジャで試料厚さ $10 \mathrm{~mm}$ になるよう 5 秒間荷重を加えたのち除重し，3 分間 放置した。このバルク状米飯を試料として 6 バイト試験を 実施した。測定は各試験区の試料についてそれぞれ 5 回行 い, 得られた粘弾性パラメー夕值の平均值を採用した。

試料の測定は, 直径 $18 \mathrm{~mm}$ の円筒形プランジャを用い て, 圧縮速度 $2.0 \mathrm{~mm} / \mathrm{s}$, 引張り速度 $1.0 \mathrm{~mm} / \mathrm{s}$ の条件下で 行い, 図 5 に示すような 6 バイト計測曲線を得た。困中に はそれぞれの圧縮に要した力を $\mathrm{H}$, 仕事量を $\mathrm{A}$, 逆に引離 しに要した力をーH，仕事量をーA として表示している. さらに, これらのパラメータから食糧庁で用いられている 米飯の品質評価指標である硬さ・こし・付着性・粘りの 4 指標が算出される，すなわち試料を圧縮したときの最大圧 縮力の值を「硬さ（H5）」，また，試料を $92 \%$ および $23 \%$ 圧縮するのに要する仕事量の比を「こし (A5/A1)」, さら に圧縮したのち引離すのに要する力と仕事量の最大值をそ 
れぞれ「付着性 $(-\mathrm{H} 5) 」$ およひ「粘り（- A 5)」と定義し ている.

\section{7. 官能評価法}

供試材料のコシヒカリおよび日本晴について, 表 3 に示 した試験区の常温および加熱処理試料それぞれをパネルに 供試した。一般成人（平均年齢 $30.4 \pm 8.9$ 歳）に対しては, 品種・加熱処理の有無・保存試験区数の組み合わせにより 総量 58 サンプルを供試した. 1 サンプル当たりのパネル数
は約 40 名であり，パネルの延べ人数は 2292 名となった。 高齢者（平均年齢 $81.1 \pm 8.4$ 歳）に対しては 10 サンプルを 供試し, 1 サンプルあたりのパネル数約 27 名, 延ベ 272 名 を対象とした。図 6 に示すような官能評価用シートを作成 して，「透明感」・「つや」・「白さ」・「香り」・「あま味」・ 「うま味」・「硬さ」・「こし」・「付着」・「粘り」・「舌触り」 などの知覚強度に関する 11 項目および総合的な嗜好度の 尺度である「おいしさ」を 7 段階尺度法により評価した。

評価には一回ごとに 1 サンプルを供試し，サンプルの摂

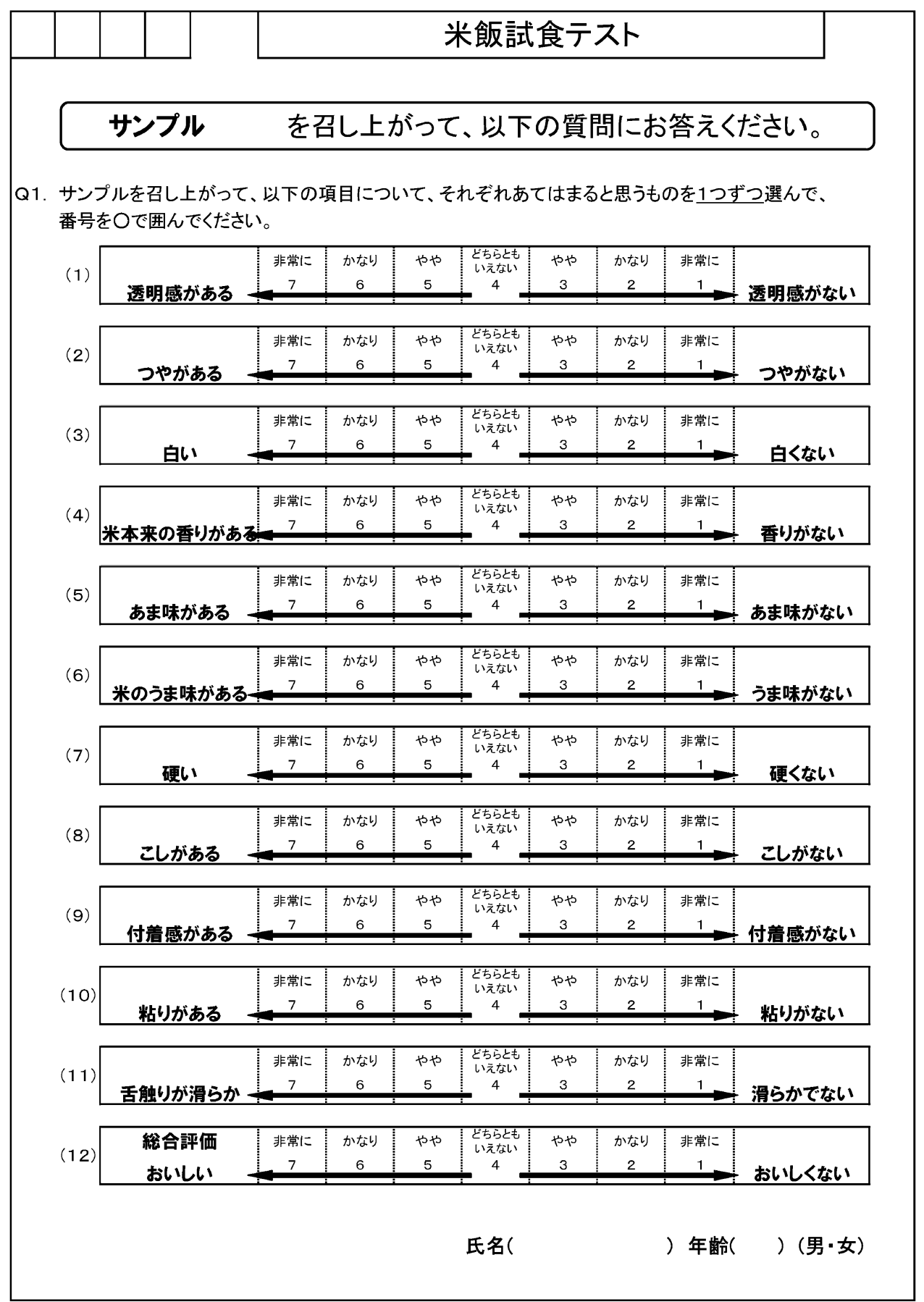

図 6 米飯の官能評価用シート 
食間には，水で口直しをしながら評価することとした。ま た，評価の前に評価用語について次のような説明を行なっ た.

・硬さ : 「ご飯を噛むときの力とする」

・こし：「ご飯の噛み応えとし，割れたり切れたりしない あの程こしがあるとする」

・付着 :「ご飯が歯にひっつく具合とし」，付着のないもの の例として豆腐やプリンを挙げた。

・粘り :「ご飯の粘りとし」，むちを例として伸びれば伸び るほど粘りがあるとした。

\section{8. $\mathrm{ANN}$ モデルの適用}

\section{1 モデルの概要}

図 7 に示すように, 本研究では $\mathrm{C}$ 言語を用いて作成した 入力層-中間層-出力層の 3 層 ANN モデルを使用した。こ のモデルは素子の出力演算にシグモイド関数を利用し，逆 誤差伝播法・逐次更新学習法により荷重修正を行った。荷

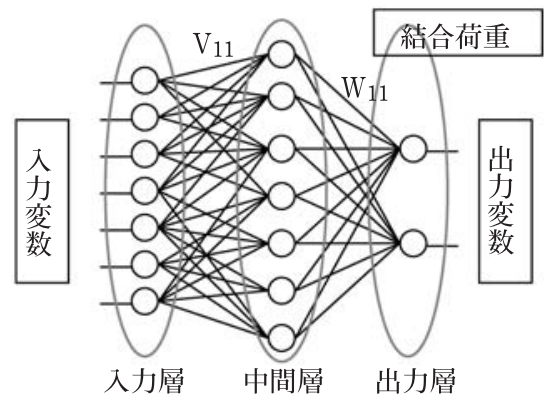

図 $7 \quad 3$ 層 ANN モデル
重初期值にー1〜 の範囲の乱数を用い，20 回の試行の上, 交差妥当化により評価される学習程度が最も高い結果を最 適な荷重として採用した。なお中間層素子数は 1～15 の範 囲で検証を行い，学習精度の向上が認められなくなる最小 の素子数を採用した。なお，近似精度は，決定係数 $\left(\mathrm{R}^{2}\right)$ お よび平方平均二乗䛊差 (Root Mean Square Error : RMSE) を用いて評価した。

\section{2 解析項目と手順}

本研究で行なった解析項目と手順の概要を図 8 に示し た。図中の実線は一般成人，点線は高齢者を対象にした解 析をそれぞれ示している。以下に図中に示した番号順に 従って, 解析の課題や内容について述べる.

1）一般成人および高齢者について官能評価で得られた 「硬さ」や「付着感」など 11 の項目得点と「おいしさ」の 関係を探る(経路 (1)).

2）保存温度・時間条件が一般成人の項目得点および 「おいしさ」の評価スコアに与える影響を評価する（経路 (2) 亡 (3).

3）テンシプレッサにより得られた 12 種類の粘弾性パ ラメー夕，すなわち低・中・高圧縮時それぞれに招ける $\mathrm{A} \cdot \mathrm{H} \cdot-\mathrm{A} \cdot-\mathrm{H}$ の值から一般成人および高齢者の項目 得点スコアを予測する（経路 (4)）。

これらの解析により，例えば図 9 に示すように，ある製 品の物性值から高齢者の感じる「硬さ」, さらには「おいし さ」を予測することが可能となる。ささらに，これらの情報 を逆に製品設計にフィードバックすることにより，高齢者 の嗜好を重視した品質設計が可能となる.

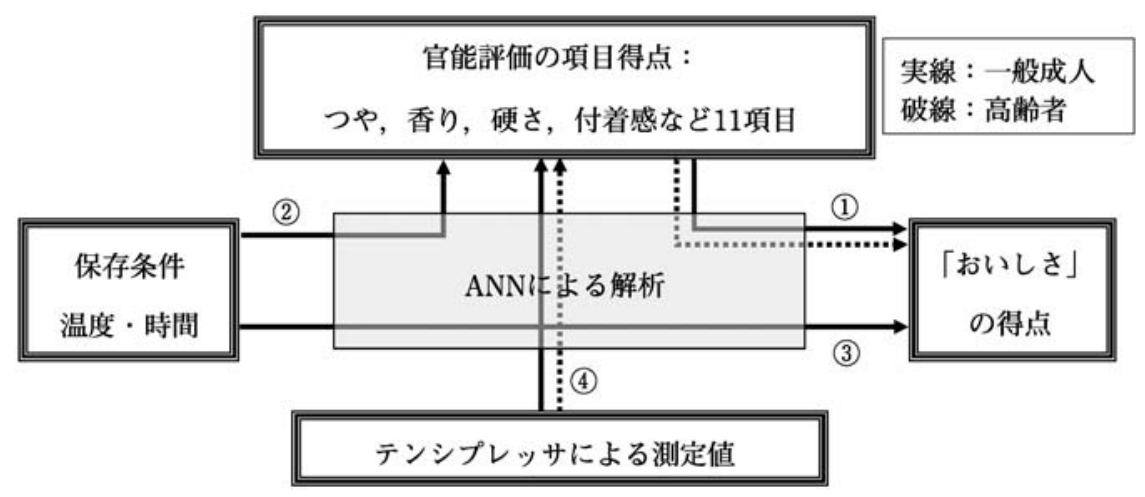

図 8 ANN モデルによる解析項目（1)～(4)）

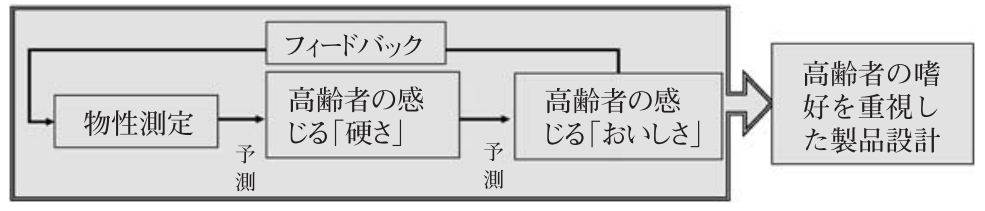

図 9 食感性モデルによる製品設計の流れ 


\section{9. 粘弾性パラメータの経時変化}

図 10 に冷蔵および凍結保存したコシヒカリの硬さ，す なわちテンシプレッサの計測パラメータ H5 の経時変化を 示した。また，「常温処理」および「加熱処理」した試料の 計測結果を区別するために，それぞれ保存温度条件に「常 温」,「レンジ」と附記して示した.

冷蔵温度 $3 \sim 7^{\circ} \mathrm{C}$ の条件下で保存した試料の硬さは保存 期間の経過に伴って，増大する傾向を示した。しかし，48 $\mathrm{hr}$ 以内であればレンジ加熱によりこの硬化が解消される ことが分かった。室温で保存した試料の硬さは冷蔵保存後 再加熱した試料と同程度に維持された。

凍結保存した試料の硬化は， $-5^{\circ} \mathrm{C}$ で保存した試料を除 いては，レンジ加熱により解消できるが，特に， $-30^{\circ} \mathrm{C}$ で

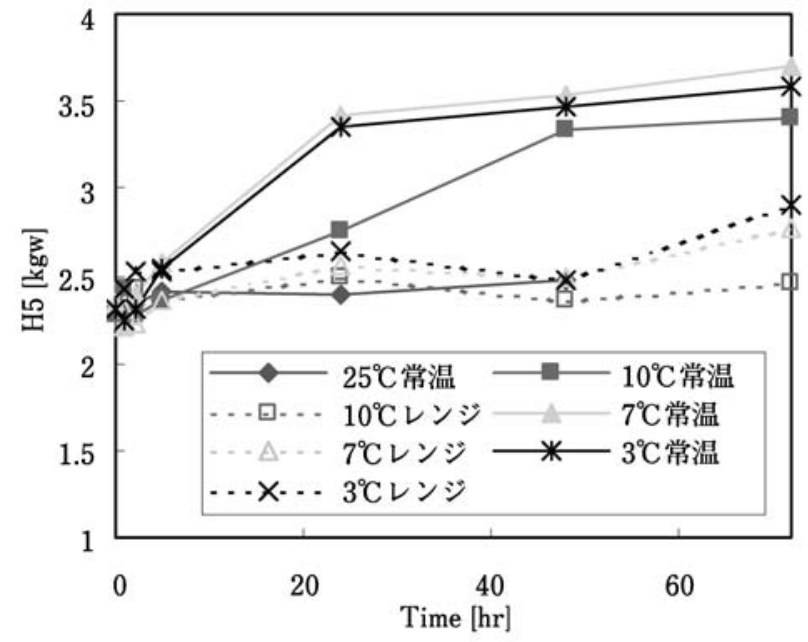

(a) 冷蔵試料
保存した試料の硬さはレンジ加熱により，ほぼ炊飯直後の 硬さに回復することが認められた。すなわち，凍結米飯の 硬化は凍結保存温度に依存し，その温度が低いほど炊飯直 後の硬さに維持されることが分かった.

図 11 には「付着感 $(-\mathrm{H} 5) 」$ の経時変化を示した。付着 感は保存期間の増大に伴って減少するが，その傾向は上述 した「硬さ」の「増大」を「減少」と読み替えることによ り，説明出来ることが分かった，すなわち「硬さ」の増大 に伴って「付着感」は減少することが確認された。他の粘 弾性パラメー夕の経時変も, 増大・減少の差はあるもの の，保存温度・時間・レンジ加熱の有無に関して，上述し た結果と同様の傾向を示すことが分かった。

これらの結果より，コシヒカリを $7 \cdot 3 ・-5^{\circ} \mathrm{C}$ で冷蔵 後, 常温処理した試料については, ほぼ全ての粘弾性パラ

図 10 コシヒカリにおける「硬さ $(\mathrm{H} 5) 」$ の経時変化

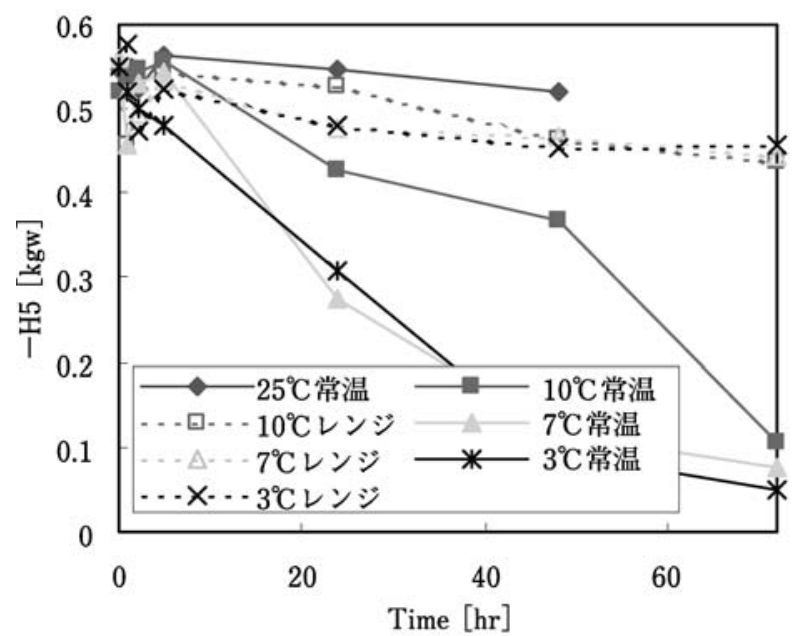

(a) 冷藏試料

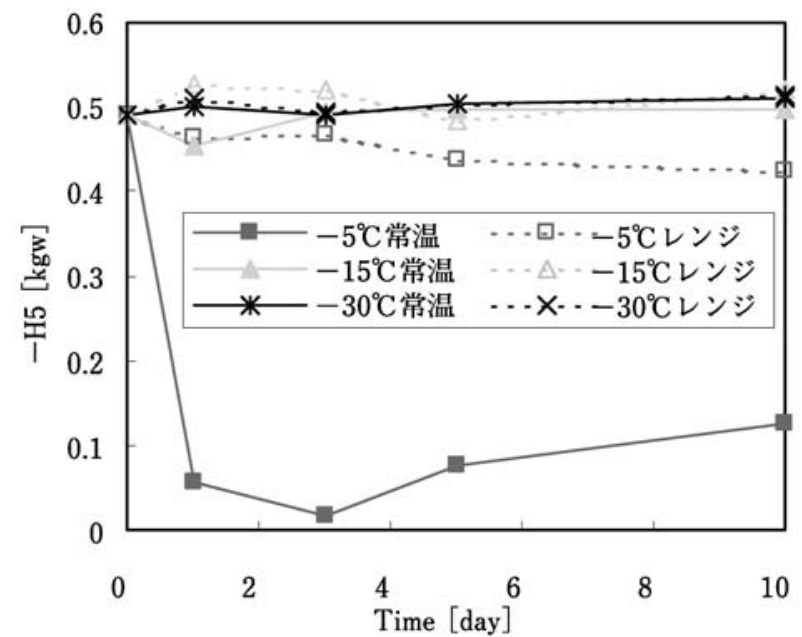

(b) 凍結保存試料

図 11 コシヒカリにおける「付着 $(-\mathrm{H} 5) 」$ の経時変化 
メー夕において大きな変化が認められ, $10^{\circ} \mathrm{C}$ 保存試料では 小さな変化が認められた。 また，これらの变化は炊飯後室 温で保存した試料よりも大きくなることが分かった。ま た, 凍結保存試料の粘弾性の変化は保存温度が低いほど小 さくなる傾向を示すが，この变化は常温処理またはレンジ 加熱処理によりほぼ解消されることが分かった。ただし， $-5^{\circ} \mathrm{C}$ で保存した試料の解消の程度は他の試料に比べて小 さい傾向を示すことが認められた.

これらの結果より，米飯の粘弾性を維持するための保存 温度条件の範囲は約 $10^{\circ} \mathrm{C}$ 以上， $-15^{\circ} \mathrm{C}$ 以下であることが 分かった.この結果は, 従来指摘されてきた保存温度条件 を裏付けるものとなっているが，これらの結果はあくまで 屯「機器測定による粘弾性特性」の変化から予測された温 度条件であり，「ヒトが感じるテクスチャーやおいしさ」の 変化から予測された条件ではない。したがって, この段階 で得られた条件下で保存した米飯に対して，消費者が「お いしい」と評価するか否かは不明である。この問題を解決 するためには，粘弾性パラメータと官能評価スコアとの関 連性を明らかにする必要があり，さらには，粘弾性特性 データから官能評価スコアを予測するモデルの出現が必要 であると考えられた，後で述べるように，本稿ではこれら の関係を明らかにし, また予測モデルの構築ツールとして ANN モデルの適用を試みた結果を紹介する。

\section{0. 一般成人および高齢者の嗜好特性}

一般成人と高齢者それぞれについて，官能評価によって 得られた 11 の項目得点を説明変数, 嗜好度すなわち総合 的な「おいしさ」のスコアを目的変数とする関数を図 7 に 示したような 3 層構造を有する ANN モデルにより近似し, それぞれの項目得点, すなわち官能評価シートに記載され ている評価項目全てのスコアと「おいしさ」との関係を明 らかにした。

ANN の入力值としては官能評価により得られた「透明 感」・「つや」・「白さ」・「香り」・「あま味」・「うま味」・「硬 さ」・「こし・「付着」・「粘り」・「舌触り」の 11 項目のス コアデータを用いた. 出力值は, 同じく官能評価により得 られた「おいしさ」の得点とした。一般成人および高齢者 の米飯に対する嗜好特性を明らかにするため, 解析には, コシヒカリ・日本晴の常温処理および加熱処理試料を対象 とした全ての官能評価結果のデータセットを用いた。すな わち，一般成人については，欠損值のあるデー夕を除いた 全デー夕数 2292 のうち, ランダムに選択した 1604 を学習 データ， 688 を検証データとして用いた．高齢者について は, 全デー夕数 272 のうち，190を学習デー夕， 82 を検証 データとした。 また, 試行の結果, 中間層の最適素子数を 一般成人では 12 , 高齢者では 10 とした。

近似精度は, 先に述べた決定係数 $\left(\mathrm{R}^{2}\right)$ および平方平均 二乗誤差（RMSE）を用いて評価した。近似の結果，一般
成人については，学習時において高い精度の近似が可能で あり $\left(\mathrm{R}^{2}=0.89, \mathrm{RMSE}=0.56\right)$ ，また検証時でも同様に高 い精度の近似が行われていることを確認した（ $\mathrm{R}^{2}=0.90$, RMSE =0.54). また，高齢者についても比較的高い精度で の近似が可能であった（学習時 $\mathrm{R}^{2}=0.82, \mathrm{RMSE}=0.72$, 検 証時 $\left.\mathrm{R}^{2}=0.64, \mathrm{RMSE}=1.04\right)$.

図 12 に一般成人および高齢者の嗜好特性の相違が認め られた項目得点と「おいしさ」との関係の典型的な例とし て，「つや」・「香り」・「うま味」・「硬さ」と「おいしさ」の スコアとの関係をそれぞれ示した。 これらの図に示すよう に，一般成人・高齢者とあに，「つや」・「香り」・「うま味」 の増加に伴って「おいしさ」を強く感じることが明らかと なった。しかし，「つや」拈よび「香り」については，高齢 者の曲線の傾きが一般成人と比較して大きいことから, 「つやと「香り」が「おいしさ」に与える影響を大きく感 じることが分かった。また，一般成人では「硬さ」が「お いしさ」に与える影響は認められなかったのに対して，高 齢者では「硬さ」の項目スコア 3 点近傍で「おいしさ」の 極大值を示し，これ以上の項目スコアの範囲では，「硬さ」 の増加に伴って「おいしさ」が減少することが分かった。 これらの結果, 高齢者は「おいしさ」に関して, 一般成人 よりあ「つや」と「香り」を重視し，極端な「硬さ」には 拒否感を示すことが分かった。

図 13 は一般成人および高齢者が感じる「こし」と「付着 感」から予測される，「おいしさ」の官能評価スコアを示し た等高線図である。なお，これらの作図に当たっては，上 記 2 項目以外の項目スコアデータについて, その平均値を 採用して，これらを固定した。 その結果，一般成人では， 「こし」と「付着感」の増加に伴い「おいしさ」あ増加する 傾向がみられたのに対して, 高齢者では,「こし」が小さく 「付着感」の高い米飯に「おいしさ」のピークが観られるな ぞ，両者の嗜好特性の相違が明らかとなった。

これらの結果に示されるように，本節では官能評価デー 夕のみを利用して ANN 解析を行うことにより, 従来の解 析手法では得られなかった有用な情報が得られることを示 した.

\section{1. 最適保存条件の探索}

\section{1 保存条件が品質特性に及ぼす影響}

一般成人を対象として，保存温度および保存時間がそれ ぞれの官能評価項目得点に及ぼす影響について, ANN 解 析を行った結果について述べる. 高齢者の被験者および供 試サンプル数は一般成人と比較して少なく，解析に十分な デー夕数が得られなかったため，本節では一般成人につい ての結果のみを報告する.

ANNの入力值としては官能評価で供試したサンプルの 保存時間・温度を用い, 出力值としては, コシヒカリの常 温処理および加熱処理試料それぞれについて, 官能評価に 

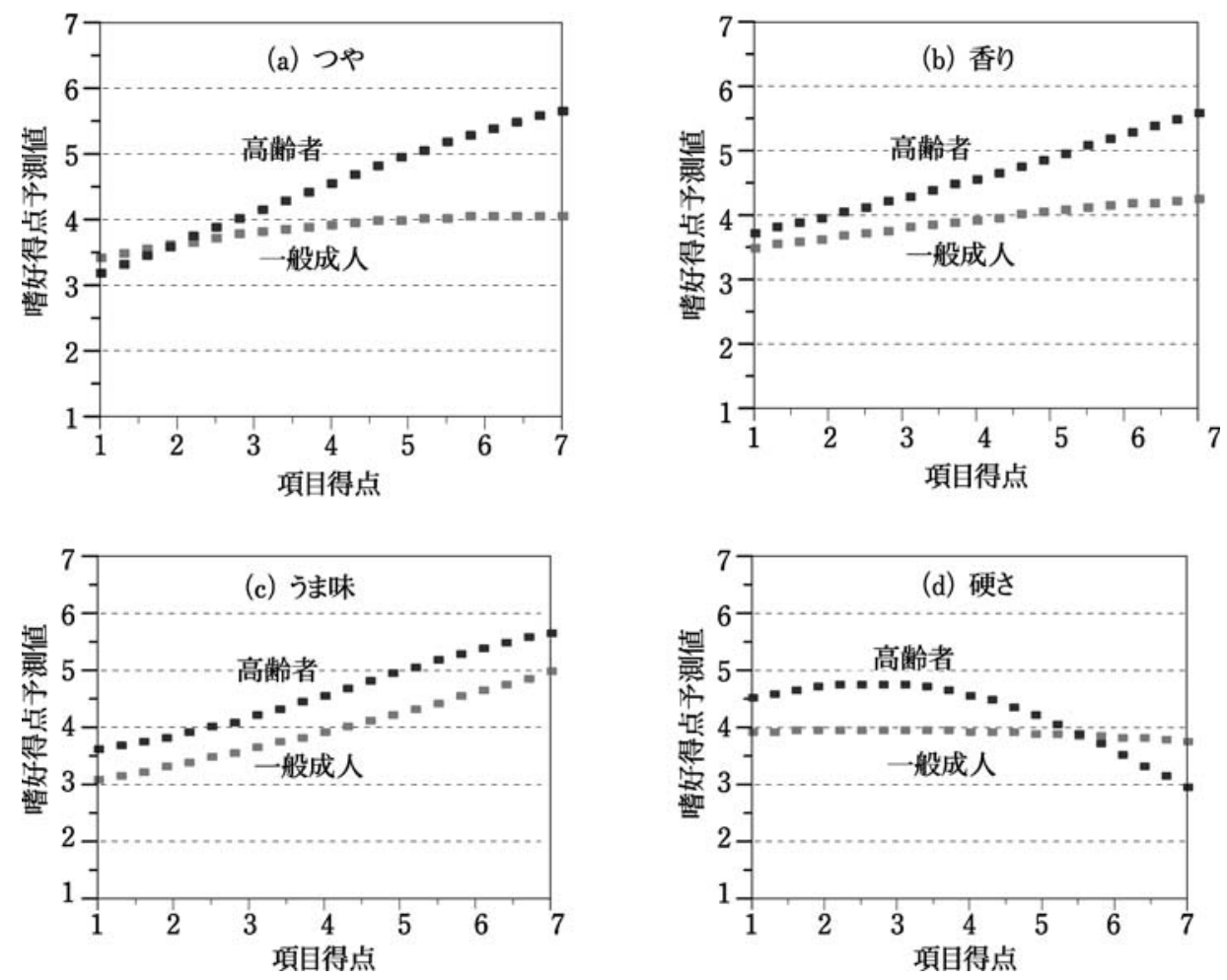

図 12 項目得点と嗜好得点「おいしさ」(一般成人と高齢者の比較)
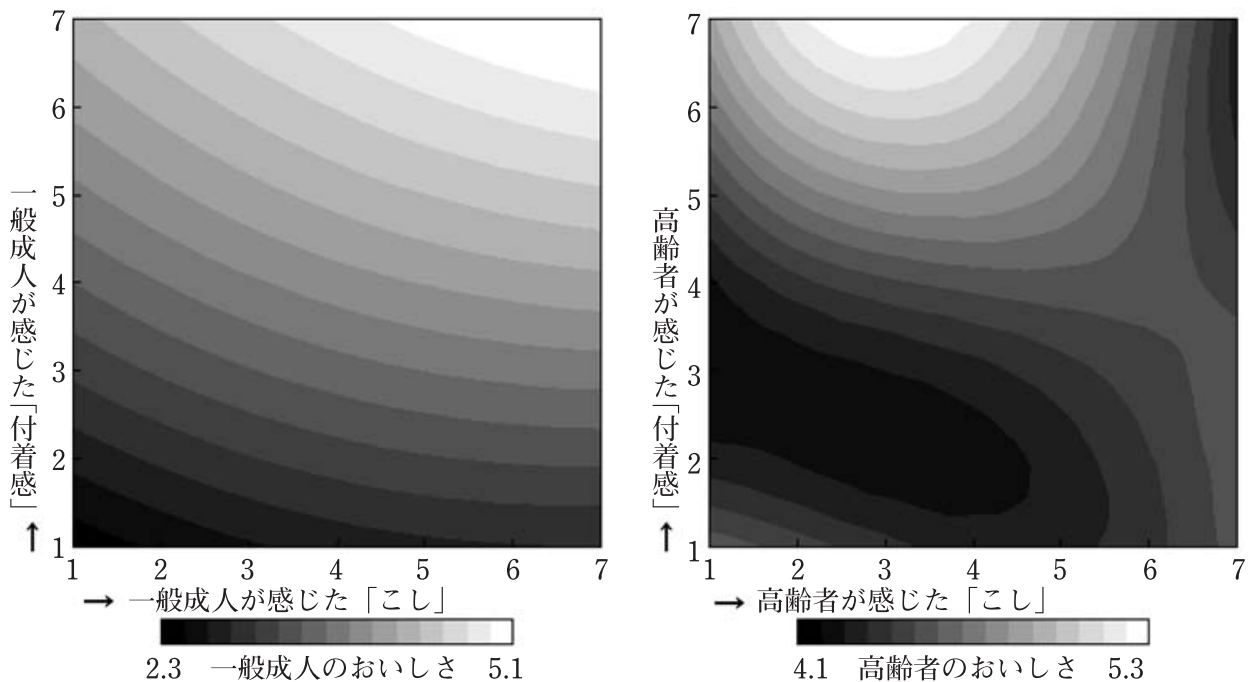

図 13 「こし」と「付着感」が「おいしさ」に及ぼす影響

より得られた 11 項目それぞれについて得られたスコアの 平均值を用いた。

図 14 は常温処理のコシヒカリについて保存温度と時間 から予測される，一般成人の「硬さ」および「付着感」の 官能評価得点をそれぞれ示した等高線図である。近似の精 度は,「硬さ」では学習時 $\left(\mathrm{R}^{2}=0.52, \mathrm{RMSE}=0.29\right)$, 検証 時 $\left(\mathrm{R}^{2}=0.60, \mathrm{RMSE}=0.38\right)$, 「付着感」では学習時 $\left(\mathrm{R}^{2}=\right.$ $0.91, \mathrm{RMSE}=0.45)$ ，検証時 $\left(\mathrm{R}^{2}=0.43, \mathrm{RMSE}=0.15\right)$ で あった。ここで，「硬さ」は保存期間中に評価得点が上昇す
る評価項目であり，他方，「付着感」は他の全ての評価項目 と同様に低下する評価項目である。これらの両評価項目は 保存期間中の経時变化の特性を典型的に示す項目として, その解析結果を採用することとした。

これらの結果，一般成人が感じる「硬さ」を 1 日間保持 するための保存温度条件としては $15^{\circ} \mathrm{C}$ 以上, 長期保存で は一 $20^{\circ} \mathrm{C}$ 以下が適当であることが分かった。同様に「付着 感」を 1 日間保持するための保存温度条件を $10^{\circ} \mathrm{C}$ 以上，長 期保存ではー $25^{\circ} \mathrm{C}$ 以下が適当であることが分かった。 

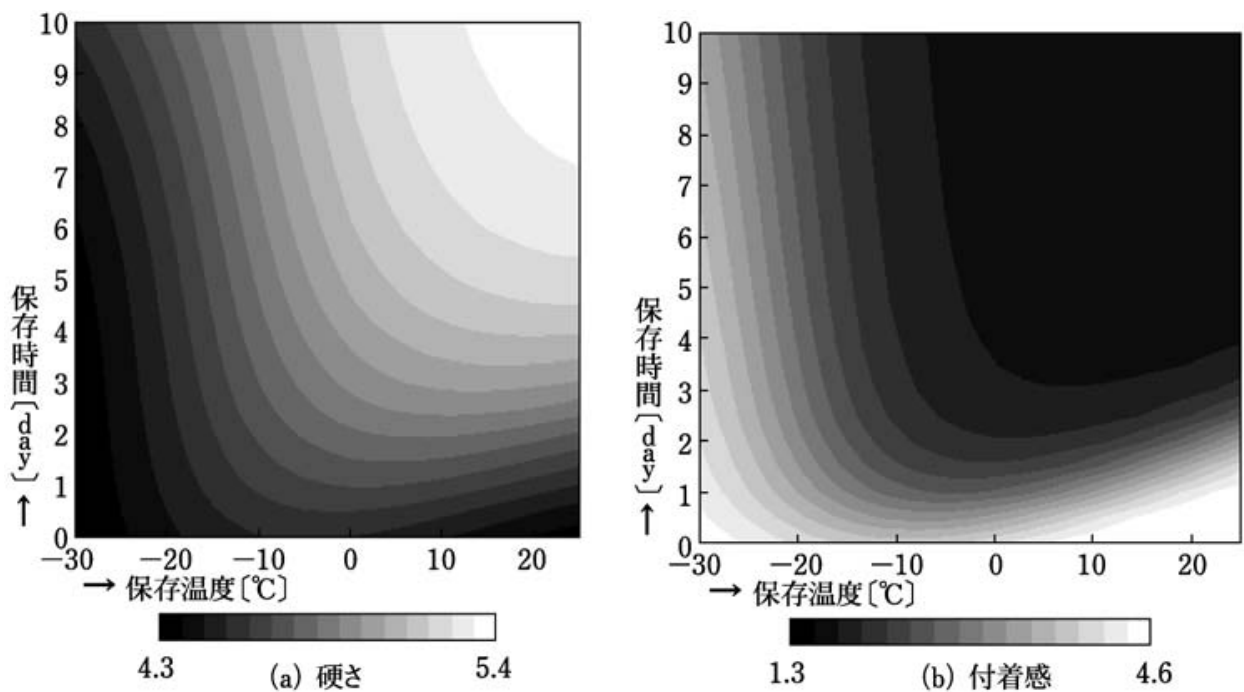

図 14 コシヒカリの保存条件と「硬さ」・「付着感」の関係（一般成人）

\section{2 保存条件が「おいしさ」に与える影響}

一般成人を対象として，コシヒカリの保存温度・時間が 「おいしさ」スコアに及ぼす影響について, ANN 解析した。 ANN の入力值としては官能評価で供試したサンプルの保 存温度・時間, 出力值には常温および加熱処理試料それ ぞれについて，官能評価による「おいしさ」スコアの平均 值を用いた。

図 15 はコシヒカリの常温および加熱処理試料について, 保存温度と時間から予測される「おいしさ」の官能評価ス コアを示した等高線図である。近似の精度は，コシヒカリ の常温処理試料では学習時 $\left(\mathrm{R}^{2}=0.89, \mathrm{RMSE}=0.46\right)$, 検 証時 $\left(\mathrm{R}^{2}=0.83, \mathrm{RMSE}=0.81\right)$, 加熱処理試料では学習時 $\left(\mathrm{R}^{2}=0.35, \mathrm{RMSE}=0.39\right)$, 検証時 $\left(\mathrm{R}^{2}=0.59, \mathrm{RMSE}=0.21\right)$ であった。

常温処理米飯の「おいしさ」を 1 日間保持するための保 存温度条件は $15^{\circ} \mathrm{C}$ 以上, 長期保存では $-25^{\circ} \mathrm{C}$ 以下が適当 であることが分かった。このように，冷凍米飯の食味保持 に最適な保存条件が明らかとなり，この結果はテンシプ レッサによる粘弾性計測結果とは異なることが明らかに なった。すなわち, 冷凍米飯の最適保存条件として, 機器 測定值のみに基づき検討した条件を採用すると, その米飯 は消費者に受け入れられない結果を招きかねないと考えら れる。

\section{3 品種による「おいしさ」の相違}

図 16 に日本晴の保存温度・時間と「おいしさ」の関係を 示す。この図では米の品種間の比較を容易にするため, 図 16 のシヒカリについて得られた結果と同一のスケールを 用いている. 常温処理米飯では, $15^{\circ} \mathrm{C}$ 以上の保存条件下に おいて，コシヒカリとの「おいしさ」の相違は認められな かったが, 凍結保存ではコシヒカリの「おいしさ」がー $25^{\circ} \mathrm{C}$ 以下で長期的に保持されるのに比べ，日本晴では全ての凍

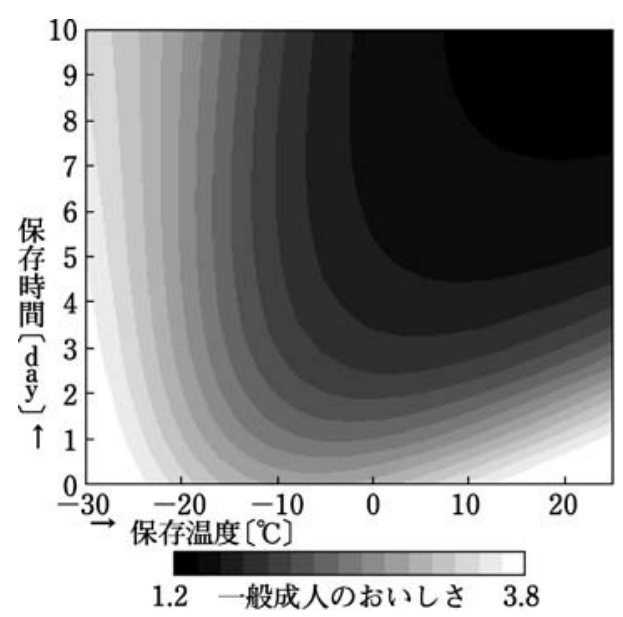

図 15 コシヒカリの保存条件と「おいしさ」の関係

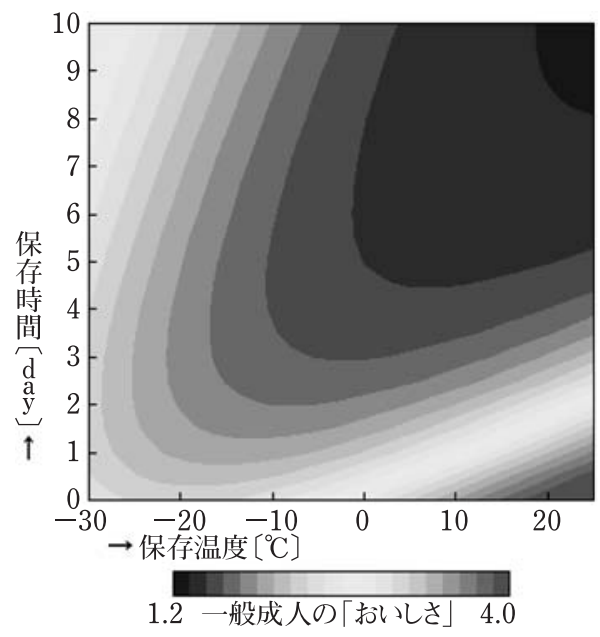

図 16 日本晴の保存条件と「おいしさ」の関係 
結保存温度条件において低下することが分かった。

加熱処理したコシヒカリの「おいしさ」では，保存温度 条件による食味変化の相違は認められず, 全ての保存温 度・期間において，ほぼ一定に維持された。これに対して， 日本晴の「おいしさ」は保存 4 日以降に大きく低下した。 このように，加熱による食味向上の程度は品種により異な ることが確認され, 加熱処理米飯の食味劣化については, 保存温度条件と比較して品種の相違が大きく影響すること が分かった。このために，コシヒカリ以外の品種に対応し た最適保存温度条件は炊飯法も含めて別途求める必要があ ることが分かった。

\section{2. 粘弾性データを用いた官能評価スコアの予測}

機器測定值から一般成人および高齢者が感じる官能評価 項目スコアを予測することを目的として，テンシプレッサ

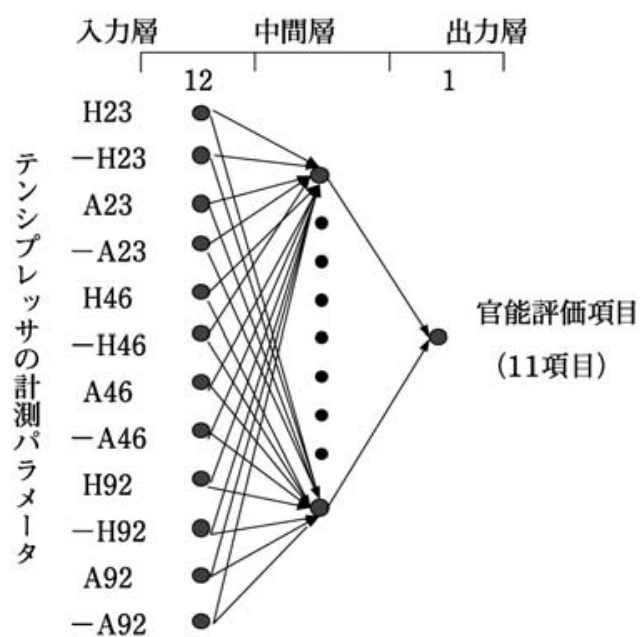

図 17 テンシプレッサのパラメータから官能評価スコアを 予測する ANN モデル

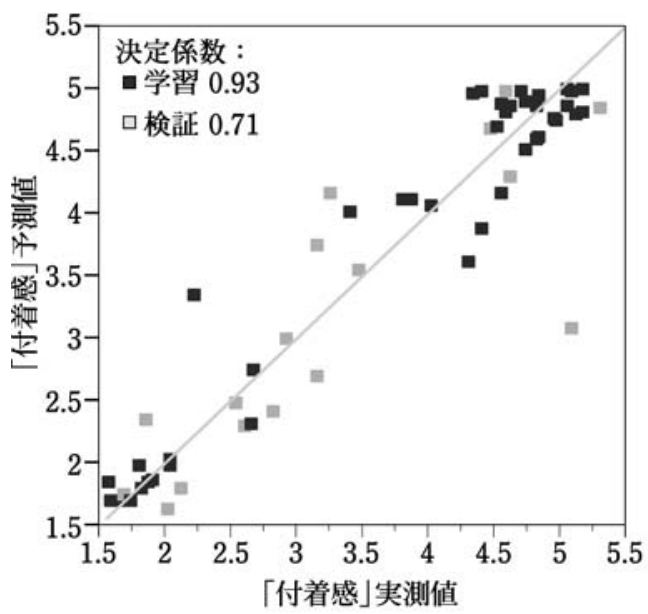

(a) 一般成人
による 12 の測定值を説明変数，一般成人および高齢者が 感じる 11 項目それぞれの官能評価得点を目的变数とする 関数をANNによりそれぞれ近似した。

図 17 に示すように, ANN の入力值としては，コシヒカ リと日本晴の常温処理および加熱処理試料それぞれについ て，テンシプレッサにより測定された 12 の測定項目デー 夕を用いた。出力值としては，コシヒカリ・日本晴の常温 処理および加熱処理試料それぞれについて，官能評価によ り得られた一般成人および高齢者が評価した項目スコアの 平均值を用いた。平均值を採用したのは，機器測定值が一 般成人および高齢者の感じるそれぞれの官能評価項目に与 える影響を明らかにすることを目的とした解析であるた め, 同一の機器測定值を示すサンプル，すなわち同一保存 条件下におけるサンプルの評価得点がパネルによってばら ついた出力值を示すのを避けるためである.

この解析による典型的な結果として，図 18 にテンシプ レッサで計測された「付着感」の実測值に対する，一般成 人および高齢者が感じる「付着感」の予測值をプロットし てそれぞれ示した。近似の精度は，一般成人では学習時 $\left(\mathrm{R}^{2}\right.$ $=0.93, \mathrm{RMSE}=0.33)$, 検証時 $\left(\mathrm{R}^{2}=0.71, \mathrm{RMSE}=0.64\right)$, 高齢者では学習時 $\left(\mathrm{R}^{2}=0.98, \mathrm{RMSE}=0.07\right)$ および検証時 $\left(\mathrm{R}^{2}=0.88, \mathrm{RMSE}=0.19\right)$ と，比較的高い精度が得られた。 また，一般成人および高齢者が感じる「付着感」の実測値 と予測值の相関係数はそれぞれ $0.94 ， 0.96$ であり，高い精 度での予測が可能となった。

以上のように，テンシプレッサによる測定值から，一般 成人・高齢者それぞれが感じる官能評価項目スコアを予測 することが可能となった，さらに，第 10 節で示したよう に，ANNにより近似した項目スコアと「おいしさ」スコア との関係を示す関数を利用することにより，項目スコアか ら「おいしさ」のスコアを予測することが可能となった。

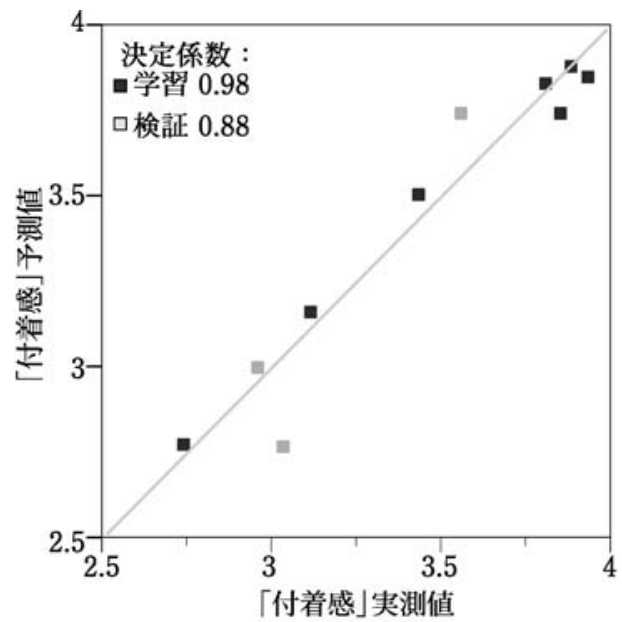

(b) 高齢者

図 18 ANNによる「付着感」の予測 


\section{3. 水結晶計測技術の開発}

\section{1 凍結食品内水結晶の挙動}

急速凍結により食品内に生成する微細な水結晶む, 凍結 保存中に次第に大きな水結晶に成長する。これは再結晶化 と呼ばれ, 凍結食品内のように不均一で多数の水結晶粒子 から成る系では, 自由エネルギー最小の原理に基づいて小 さなサイズの水結晶は消失し, 大きなサイズの水結晶はさ らに成長することが知られている。

凍結食品中の水結晶サイズが増大すると細胞組織は圧 迫・破壊されてその構造が崩れ, 細胞全体の本来の調和が 失われるために品質劣化が生ずる. すなわち, 再結晶化は 凍結保存中の食品における品質劣化要因の一つであり, 食 品内水結晶を計測することは, 食品の最適凍結操作法およ び保存法の確立に有用であると考えられる。

本研究でも $-5^{\circ} \mathrm{C}$ で凍結保存した試料の粘弾性パレメー 夕は著しく変化し, レンジ加熱してもテクスチャーの回復 は他の試料に比べて若干困難であることを述べた．この原 因は冷凍条件に依存する氷結晶サイズにあるあのと想定さ れた。 そこで, 本研究では氷結晶計測技術の開発レベルを 冷凍米飯 1 粒子内の水結晶観察を可能とするレベルに設定 した。

\section{2 計測手法の検討}

食品材料の凍結時において, 材料内水結晶は溶質または 不純物を排除する形で形成されるため, 食品の主要構成成 分である糖質, タンパク質および脂質などを染色し, 非染 色部分を水とみなすことにより水結晶性状の観察が可能に なると考えられた。そこで，各種の染色剂を添加した水で 炊飯・染色した後で凍結し, マイクロスライサ画像処理シ ステムで水結晶を計測する方法を試みた。 その結果, Rhodamine 蛍光試薬を炊飯水に $0.1 \%$ 添加することにより水 結晶を可視化することに成功した.

\section{3 水結晶の観察結果}

図 19 と 20 はそれぞれ $-5^{\circ} \mathrm{C}$ およびー $30^{\circ} \mathrm{C} て ゙ 50$ 日間保 存した試料の断面画像である. 図 20 に示した画像は炊飯 直後に観察したものと同様であり，水結晶サイズは冷凍条 件と保存期間に依存しないことが確認された。この図に示 すように, 米飯粒の周辺部は中心部と比較して, 色が濃く, 水分濃度が高いことが分かった。 また，中心部の拡大図に 示すように, この部分では長径 $150 \mu \mathrm{m}$, 短径 $100 \mu \mathrm{m}$ ほど の団粒状構造が観察された。一般に，コメの可食部である 肧乳部では, 長径 $100 〜 200 \mu \mathrm{m}$, 短径 50〜 $100 \mu \mathrm{m}$ ほどの 細胞に, 直径約 $5 \mu \mathrm{m}$ のデンプン粒が 10〜20 粒のグループ をなして詰まっていることが知られている，従って，図中 の団粒状構造はコメの細胞組織が観察されたものであり,

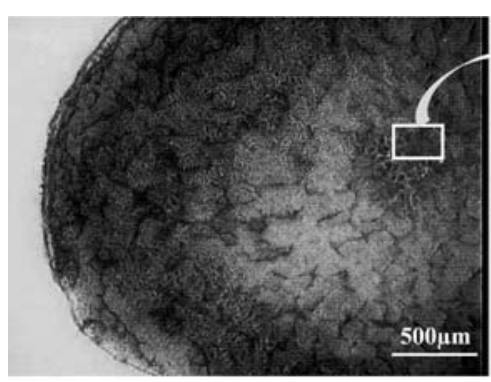

(a) $-5^{\circ} \mathrm{C}-50$ day 保存試料

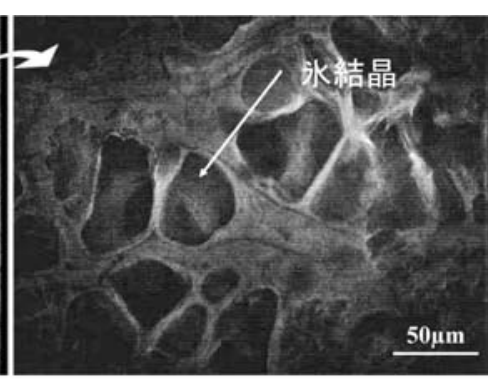

(b) 試料中心部の断面拡大画像

図 19 凍結保存試料 $\left(-5^{\circ} \mathrm{C}, 50 \mathrm{day}\right)$ 内の水結晶画像

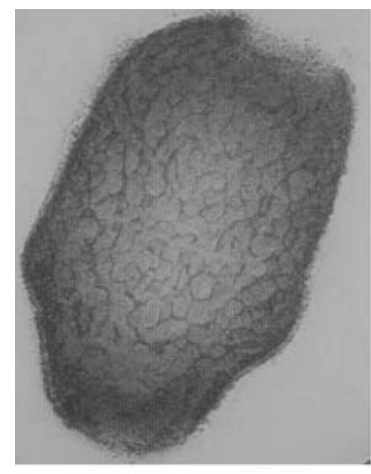

(a) $-30^{\circ} \mathrm{C}-50$ day 保存試料

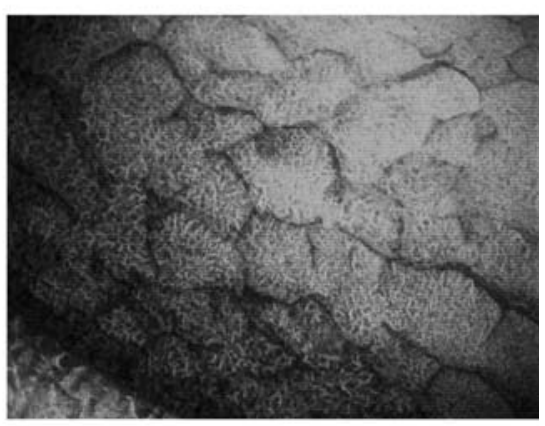

(b) 試料中心部の断面拡大画像

図 20 凍結保存試料 $\left(-30^{\circ} \mathrm{C}, 50 \mathrm{day}\right)$ 内の水結晶画像 
微細な水結晶が細胞間隙に存在するあのと, 細胞質内に存 在するものに分けられ, 細胞粒内に形成される水結晶は, サイズ 15〜30 $\mu \mathrm{m}$ の球状であることがわかった.

図 19 に示すように, $-5^{\circ} \mathrm{C}$ の条件下で凍結保存した試料 では氷結晶の成長が顕著であることが分かった。 また，凍 結保存米飯の米粒内水結晶の成長が, 先に示した物性值 - H5 などの粘弾性変化の一因であることが示唆された. 以上の結果より, 本研究で開発された冷凍米飯内水結晶の 計測法は, 冷凍条件と氷結晶構造との関係を定量的に明ら かにする手法として有用であることが確認された。

\section{4. おわりに}

本稿で紹介した冷凍米飯の最適保存条件を探索する研究 は，「食感性工学」の手法を実用技術分野に展開する方法論 と研究結果の有用性を示したものと考える. 特に, ANN モデルによる解析は, 消費者起点工学を具体的に実現した 典型例として評価され, 今後の研究開発手法にもブレーク スルーをもたらすむのと期待されている。例えば，本研究 で得られた方法を活用し, (冷凍操作条件) - (計測機器に よる品質劣化要因のパラメーター) - (官能評価結果) の 3 者間に存在する関係を解明していくと共に, 冷凍米飯の配 送条件, すなわち, 時間・距離・包装・温度などの組み合 わせによる各種条件下における最適な冷凍操作条件を提示 するシステムの構築が可能になると考えられる.

さらに, これらの研究成果は, 国内のみならず米国や中 国などにおける広域流通を対象としたマーケテング戦略の 立案を可能とする基礎技術としても有用となるむのと考え る. 今後, 冷凍食品が, レストラン, コンビニエンススト アおよび家庭などから廃棄されるごみの削減, 食品供給の 安定化, 食品製造業における深夜作業負荷の平準化および 削減などに果たす役割は大きい。

他方, 我が国をはじめ, 米を主食とするアジア各国にお いて, 冷凍米飯の品質の向上と普及は重要な課題となって いるが, 特に, 我が国においては, 今後, 介護を要する高 齢者のための施設の不足から，健康食および介護食の宅配 による供給が必要となるあのと考えられている。本研究で 得られた成果が, 消費者の嗜好に合った「おいしく簡単に 食べられる健康で安全な食」を提供する社会システムの構 築にも貢献するあのと思われる.

\section{文献}

1）相良泰行, 食感性工学のパラダイムと展望, 食科工， 56 , 309-316 (2009).

2）相良泰行, 食感性モデルによる「おいしさ」の評価法, 食科 工，56，317-325 (2009).

3）相良泰行, 味と香りの感性計測システム, 食科工， 56, 429443 (2009).

4）相良泰行, 食品の力学的物性とテクスチャ一の感性計測法, 食科工，56，501-512 (2009).

5) Bomio, M., Neural networks and the future of sensory evaluation, Food Technol., 52, 62-63 (1998).

6) $\mathrm{Ni}, \mathrm{H}$. and Gunasekaran, S., Food quality prediction with neural networks, Food Technol., 52, 60-65 (1998).

7) Sitakalin, C. and Meullenet, J.F., Prediction of Cooked Rice Texture Using an Extrusion Test in Combination with Partial Least Squares Regression and Artificial Neural Networks, Cereal Chem., 78, 391-394 (2001).

8）日本統計協会, 「高齢人口之高齢者のいる世帯」（総務庁統 計局編) p. 21 (2000).

9）貝沼やす子, 品種, 貯蔵期間, 炊飯条件が異なる冷凍保存米 飯の解凍時の性状, 家政誌, 47, 15-23 (1995).

10）貝沼やす子，米の種類，炊飯条件が異なる冷凍保存米飯の 解凍時の性状 (第 2 報), 家政誌, 47, 49-57 (1996).

11) Takeuchi, S., Maeda, M., Gomi, Y., Fukuoka, M. and Watanabe, H., The Change of Moisture Distribution in a Rice Grain During Boiling as Observed by NMR Imaging, J. Food Engineering, 33, 281-297 (1997).

12）貝沼やす子, 温水浸漬が低温保存米飯のテクスチャ変化に 及ぼす影響， 51，15-21（2000）。

13）成宮正興, 米飯のアルファ凍結, 冷凍, 71，326-333 (1996).

14）矢内和博, 三浦 靖, 中村良司, 西ノ宮武, 原田 努, 小林 昭一, 冷凍米飯の品質に及ぼす凍結, 貯蔵抢よび解凍条件 の影響, 食科工，48，777-789（2001）.

15）成宮正興，冷凍米飯の大量解凍法，食品工学， 42， 35-41 (1999).

16）岡部元雄, 米飯の食味に関する研究, New Food Industry, 19，65-71 (1977).

17）大坪研一編,「米飯食品ビジネス事典」，（サイエンスフォー ラム，東京）（2001）。

18）竹生新治郎,「米の科学」, 石谷孝佑 - 大坪研一 (編), (朝倉 書店, 東京) (1995)。

19) Okabe, M., Texture Measurement of Cooked Rice and its Relationship to the Eating Quality, J. Texture Stud., 10, 131-152 (1979).

20）岡留博司, 豊島英親, 大坪研一, 単一装置による米飯物性の 多面的評価，食科工，43，1004-1011（1996）.

21）岡留博司, 豊島英親, 須藤 充, 安東郁男, 沼口憲治, 堀末 登, 大坪研一，米飯 1 粒の多面的物性測定に基づく米の食 味評価, 食科工, 45, 398-407 (1998).

22) Ramesh, M., Zakiuddin Ali, S. and Bhattacharya, K.R., Structure of rice starch and its relation to cooked-rice texture, Carbohydrate Polymers, 38, 337-347 (1999).

23) Bhattacharya, K.R. and Sowbhagya, C.M., Pasting Behavior of Rice, A New Method of Viscography, J. Food Science, 44, 797-804 (1979).

24) Ohtsubo, K., Julie J.H. Siscar, Bienvenido O. Juliano, Iwasaki, T. and Yokoo, M., Comparative Study of Texturometer and Instron Texture Measurements on Cooked Japanese Milled Rices, Rep. Natl. food Res. Inst., 54, 1-9 (1990).

25) Ogawa, Y., Sugiyama, J., Kuensting, H., Ohtani, T., Hagiwara, S., Liu, X.Q., Kokubo, M., Yamamoto, A., Kudoh, K. and Higuchi, T., Advanced Technique for Three Dimensional Visualization of Compound Distributions in a Rice Kernel, J. Agricultural and Food Chemistry, 49, 736-740 (2001).

26) Horigane, A.K., Toyoshima, H., Hemmi, H., Engelaar, W. M.H.G., Okubo, A. and Nagata, T., Internal Hollows in Cooked Rice Grains (Oryza sativa cv. Koshihikari) Observed by NMR Micro Imaging, J. Food Science, 64, 15 (1999).

27) Horigane, A.K., Engelaar, W.M.H.G., Toyoshima, H., Ono, H., Sakai, M., Okubo, A. and Nagata, T., Differences in 
Hollow Volumes in Cooked Rice Grains with Various Amylose Contents as Determined by NMR Micro Imaging, J. Food Science, 65, 408-412 (2000).

28）渡辺尚彦, 核磁気共鳴 (NMR) イメージング法の食品科学 への適用，食工誌，41，448-455（1994）.

29）石田信昭, 小泉美香, 小川秀一郎, 狩野広美：ミクロ MRI
と食品科学, 食科工， 47，407-423（2000）.

30）相良泰行, 食感性工学による高齢者介護食サプライシステ ムへの展開，冷凍，78，26-29（2003）.

(平成 21 年 9 月 16 日受理) 